\author{
EWA LIPIŃSKA \\ (D) https://orcid.org/0000-0002-9260-4885 \\ Uniwersytet Jagielloński \\ Kraków
}

\title{
Język polonijny czy języki polonijne?
}

Polish diaspora language or Polish diaspora languages?

\begin{abstract}
The paper addresses aspects of the language of the Polish diaspora and of the standard language, as forms of language spoken by Poles living abroad. The standard language is/should be common for all Poles - used everywhere and by everyone in the same way. The Polish diaspora language, on the other hand, appears only in specific territories and is used for communication in specific groups of Poles. It differs depending on the country where they settled and on the language it comes into contact with, as well as on the diversity of the emigrants, and also depending on the Polish they brought from their home country (either them themselves or their parents). Although the terms "Polonia" [Polish diaspora] and "język polonijny" [Polish diaspora language] are commonly used, one should be aware that the latter are actually numerous.
\end{abstract}

Key words: Polish diaspora, Polish diaspora language, interferences, code switching

Termin ,język polonijny” używany często zarówno w naukowych wywodach, jak i w znaczeniu potocznym sugeruje, że jest jeden, tak jak termin „Polonia” - że istnieje tylko jedna. W niniejszym artykule chcemy zwrócić uwagę na wielowymiarowość tychże określeń. Nie ma jednej Polonii i nie ma jednego języka polonijnego, łączą je jednak wspólne cechy - wyznaczniki, które uprawniają do takich uogólnień.

Zdaniem Hieronima Kubiaka (1990) Polonie tworzą ludzie, którzy maja polskie pochodzenie i przejawiają zainteresowanie polską kulturą, choć często różni ich kraj urodzenia i stopień znajomości polszczyzny. Związki z kulturą narodową osiedleńcy zachowują też w drugiej generacji i/lub w dalszych pokoleniach, na różnym poziomie identyfikowania się z polskimi sprawami. 
Na stronie internetowej Ministerstwa Spraw Zagranicznych ${ }^{1}$ czytamy:

Lacińskim słowem Polonia - znaczącym po prostu Polska - najczęściej określa się cała polską diasporę. W węższym rozumieniu „Polonia” to słowo określające tych, którzy urodzili się już poza Polska, jednak poczuwają się do polskiego pochodzenia i związków z polskością. Terminu Polonia z reguły używamy wobec polskich społeczności w takich krajach jak USA, Kanada, Francja, Brazylia, gdzie dominują ci, których dziadkowie lub pradziadkowie wyjechali z Polski całe dziesięciolecia temu.

Następuje też wyjaśnienie:

„Polska diaspora” jest pojęciem najszerszym, obejmuje bowiem wszystkich Polaków, osoby polskiego pochodzenia i wywodzące swoje korzenie z Polski, żyjących poza granicami Polski. Z tego terminu częściej korzystaja opracowania naukowe aniżeli sami członkowie diaspory.

Dodatkowo sprecyzowano określenie „Polacy zagranicą, bo nie jest ono - zdaniem rządu tożsame z "Polonią"2. Widać to choćby w nazwie święta „Dzień Polonii i Polaków za Granicą” obchodzonego 2 maja.

„Polacy za granicą” - nie licząc polskich obywateli, którzy znajdują się za granicą czasowo i niedługo, jak np. turyści, osoby w trakcie podróży służbowych - to Polacy (często polscy obywatele), które wprawdzie żyją za granica już od dawna, ale decyzja o pobycie za granica zapadła bez ich udziału lub decydowali się pozostać za granicą czasowo, wierząc, że po odzyskaniu przez Polskę niepodległości, powrócą do niej. Do tej grupy należą Polacy żyjący na terenach, które przed II wojną światową należały do Polski. Oni nigdy nie decydowali się na opuszczenie Polski - to Polska ,wysunęła im się spod nóg” w związku z przesunięciem granic.

Nazewnictwo nie jest więc precyzyjne i pozostawia otwarte drzwi dla różnych interpretacji. Uściślijmy zatem, czy „Polonia” i „diaspora polska” to takie same pojęcia i czy można stosować je wymiennie.

${ }^{1}$ https://www.msz.gov.pl/pl/polityka_zagraniczna/polonia/definicje_pojecia/, 2012 r. [dostęp: 11.02.2019].

2 Wzmiankuje o tym S. Dubisz (1997a), który stosuje pisownię: „Polacy z zagranicy”, do czego się przychylam. Nazwa „Polacy zza granicy” sugeruje ograniczoną liczbę emigrantów, którzy osiedlili się u naszych sąsiadów. 
Faktem jest, że termin „Polonia” powstał w związku z imigracją polską w Stanach Zjednoczonych w końcu XIX wieku, ale z czasem zakres jego znaczenia zawężał się lub poszerzał. Dziś odnosi się już nie tylko do tradycyjnych skupisk zaoceanicznych (USA, Kanada, Brazylia) i historycznych (jak popowstaniowa emigracja we Francji). Coraz częściej używa się określenia „Polacy z zagranicy” w stosunku do wszystkich rodaków mieszkających poza Polska. W nazwie święta 2 maja jest więc pewna niezręczność, choć rzeczywiście niełatwo jest nazwać osoby, które nie wyjechały z ojczyzny, a ojczyzna została im zabrana. Jest także wiele innych, trudnych do nazwania skupisk, które nie podlegaja prostej kwalifikacji. Słuszne wobec tego wydaje się stanowisko MSZ w sprawie nazwy „diaspora polska”, która powinna zająć najwyższe miejsce w hierarchii terminologicznej, gdyż odgrywa w niej pierwszoplanową rolę i ma najszerszy zasięg, tym bardziej, że jej tłumaczenie na języki obce jest adekwatne - w przeciwieństwie do określenia 'Polonia'. Ponadto pojęcie 'diaspora’3, „które jest bardziej pojemne niż pojęcie emigracji lub Polonii, pozwala traktować łącznie emigrantów zarobkowych, uchodźców popowstaniowych, deportowanych, wysiedlonych i mniejszości narodowe" (Walaszek 2001).

Dochodzimy zatem do przekonania, że „diaspora” jest pojęciem nadrzędnym (inkluzywnym), lecz nie w stosunku do jednej Polonii, lecz wielu Polonii, gdyż „nie da się wskazać, a co za tym idzie opisać, więzi społecznych, które łączyłyby całość genetycznie polskich grup społecznych i tym samym umożliwiałyby traktowanie ich jako jednej zbiorowości” (Paluch 1976, 22). Wynika stąd, że należy postrzegać każdą oddzielnie, a więc odnosić się do, przykładowo, Polonii amerykańskiej, Polonii australijskiej, Polonii włoskiej, Polonii niemieckiej, Polonii szwedzkiej itd.

O zróżnicowaniu poszczególnych Polonii decyduje wiele czynników. Zdaniem Józefa Porayskiego-Pomsty $(1989,4)$ są nimi:

1) kraj osiedlenia,

2) przyczyny znalezienia się poza granicami Polski,

3) czas przebywania poza Polska,

4) zwartość polskiej grupy etnicznej,

5) zróżnicowanie pokoleniowe Polonii,

6) stopień znajomości języka polskiego (odmiany ogólnej lub regionalnej),

3 Warto wiedzieć, że terminem „diaspora” (pochodzącym z greckiego słowa „rozproszenie”) pierwotnie określano skupiska Żydów mieszkających poza Ziemią Świętą (poza Palestyna). Może dlatego był i jest rzadziej używany w stosunku do innych zbiorowości, ponieważ wydaje się być ,zarezerwowany” właśnie dla Żydów. 
7) warunki i możliwości używania języka polskiego w kraju osiedlenia,

8) status Polaków i języka polskiego w kraju osiedlenia,

9) aspiracje kulturalne Polaków mieszkających za granicą.

Determinanty te 4 można ułożyć inaczej - część grupując, część eliminując, dodając nowe $\mathrm{i} /$ lub nazywając istniejące nieco inaczej. Dzięki temu uzyskuje się pełniejszy obraz przyczyn niejednolitości Polonii. Proponujemy więc cztery zasadnicze czynniki, które są pokrótce omówione poniżej (bez numeracji, aby nie sugerować ich kolejności czy ważności):

- kraj osiedlenia,

- przyczyny znalezienia się poza granicami Polski (rodzaje emigracji),

- czas przebywania poza Polską i zróżnicowanie pokoleniowe Polonii,

- stopień znajomości języka polskiego (odmiany ogólnej lub regionalnej).

Przyczyny znalezienia się na obcym gruncie są bardzo zróżnicowane, choć zwyczajowo wyodrębnia się dwie wiodące kategorie: emigrantów politycznych i ekonomicznych5. W XXI wieku znacznie przeważaja ci drudzy, którzy przebywaja na obczyźnie dobrowolnie przez określony czas. Pierwsi - przeciwnie - zazwyczaj pozostaja poza Polską na stałe. Wpływa(ło) to inaczej na zwartość ich grupy etnicznej, znajomość lokalnego języka ${ }^{6}$, kultywowanie polskości i zróżnicowanie pokoleń. Emigranci przymusowi nie mieli wyboru miejsca osiedlenia lub wybór ten był ograniczony, zarobkowi zaś sami decydują o tym, w którym kraju chcą osiąść. To okazuje się posunięciem kluczowym, gdyż jednocześnie wybierają dla siebie i swojego potomstwa (często też dla rodziców i innych krewnych) drugi język, godzą się ze statusem imigranta zależnym m.in. od polityki etnicznej kraju przyjmującego, która dopuszcza lub uniemożliwia kultywowanie polskości oraz jej transmisję, a także akceptują odległość dzielącą ich od kraju pochodzenia.

Dodatkowo na postać Polonii wpływa pochodzenie jej członków, bo choć wszyscy wywodzą się z Polski, należy uściślić, że to kwestia widziana zbyt szeroko, zwykle bowiem chodzi o mała ojczyznę, czyli najbliższe otoczenie człowieka, środowisko społeczne, z którym dana jednostka ma bezpośredni

4 Zob. też czynniki określające zbiorowość polonijną w USA wymienione przez S. Dubisza (1997b, 259).

5 O typologii zjawiska wychodźstwa zob. Lipińska 2006, 2007, 2013. Pomijamy tu przypadki emigracji spowodowanej takimi motywami, jak: ciekawość świata, nauka/praca, chęć ucieczki, wyjazdy za „głosem serca” oraz kategorię tzw. rezydentów, gdyż nie wpływają znacząco na kształt danej Polonii.

${ }^{6} \mathrm{O}$ roli języka kraju przyjmującego dla imigranta zob. m.in. Lipińska 2016, 2019. 
kontakt oraz o bezpieczne umocowanie w znanej rzeczywistości. Nierozerwanie wiąże się z tożsamością regionalną, której przejawem jest trwanie przy własnym dialekcie i kulturze (szerzej zob. Lipińska 2018.). Oddziałuje to w istotny sposób na idiolekt danej jednostki - tak samo jak jej wykształcenie i zawód, co ma szczególne znaczenie w przypadku emigracji masowej (tzw. fal) i łańcuchowej. Oznacza bowiem osiedlanie się na danym terenie większych grup we wzajemnej bliskości, składających się z osób pielęgnujących identyczne lub podobne zwyczaje i władających taką samą lub zbliżoną odmiana polszczyzny.

Emigracja oraz imigracja muszą być rozpatrywane w szerszej perspektywie niż tylko wyjazd z własnego kraju i przyjazd do innego państwa, ponieważ zmiana miejsca zamieszkania powoduje liczne, nieraz głębokie, zmiany w życiu danej osoby. Jedną z nich jest kwestia komunikowania się, choć migrant rzadko zastanawia się nad tym, co się stanie z jego natywnym językiem w nowych warunkach. Sądzi na ogól, że pozostanie z nim i w nim, że nadal będzie pełnił tę samą funkcję. Tymczasem długotrwałe zanurzenie w obcym żywiole, przy jednoczesnym porzuceniu swojego, modyfikuje sposób porozumiewania się, a przede wszystkim - samą polszczyznę (zarówno w postaci werbalnej, jak i niewerbalnej), która natychmiast z 'krajowej' staje się 'zagraniczną' Z powodu oddalenia od macierzy J1 utrzymuje się w postaci przywiezionej z Polski, stopniowo ulegając swoistemu zamrożeniu. Nie dotykaja go szybko postępujące zmiany, jak to ma miejsce w wersji krajowej, a stały $\mathrm{i}$ intensywny kontakt $\mathrm{z}$ innym językiem odciska na nim niezmywalne piętno. O ile w Polsce język ojczysty był narzędziem kontaktu ze wszystkimi jego nosicielami we wszystkich sferach życia, to w kraju osiedlenia jest pomocny jedynie w komunikacji interetnicznej ${ }^{7}$. Staje się językiem funkcjonalnie drugim, o mniejszym znaczeniu, zasięgu i niższej randze, a prymat obejmuje kod dominujący na danym terenie.

Status polszczyzny zmienia się w zależności od pokolenia: dla dorosłych emigrantów, którzy dokonali aktu przemieszczenia się, będzie to nadal język pierwszy/ojczysty ${ }^{8}$, lecz w funkcji sekundarnej, a dla ich dzieci, czyli poko-

\footnotetext{
${ }^{7}$ Komunikacja interetniczna odbywa się po polsku w kręgu własnej grupy narodowościowej. Komunikacja ekstraetniczna wymaga posługiwania się językiem kraju osiedlenia (j.k.e.) z tubylcami oraz przedstawicielami innych grup mniejszościowych, zob. Porayski-Pomsta $(1997,205)$.

8 Pojęcia ,język pierwszy” i ,język ojczysty” w sytuacji emigracyjnej nie zawsze są synonimiczne. Tam język, który jest ojczystym rodziców, pozostając pierwszym opanowanym przez dziecko, nie spełnia wszystkich kryteriów odnoszących się do ,języka ojczystego” używanego, poznawanego, doświadczanego w kraju (zob. Lipińska, Seretny 2018).
} 
lenia polonijnego, staje się językiem odziedziczonym (JOD). Jest nabywany w sposób naturalny drogą słuchowo-ustną i w tej postaci używany w podstawowych obszarach komunikacyjnych, takich jak: dom, rodzina, sąsiedztwo, kościół oraz własna społeczność. Jeśli dzieci emigrantów uczęszczają do polskiej szkoły, poznaja język edukacyjny, który jest bliski standardowej polszczyźnie krajowej. Ich kompetencje ulegają więc znacznemu poszerzeniu, zwłaszcza w obrębie sprawności manualno-wzrokowych (zob. Lipińska, Seretny 2018).

Diagram 1 przedstawia graficzną formę (nieco uproszczonego dla potrzeb niniejszego artykułu) podziału zagranicznego języka polskiego (więcej zob. m.in. Miodunka 1990a, 15; Lipińska 2017, 86).

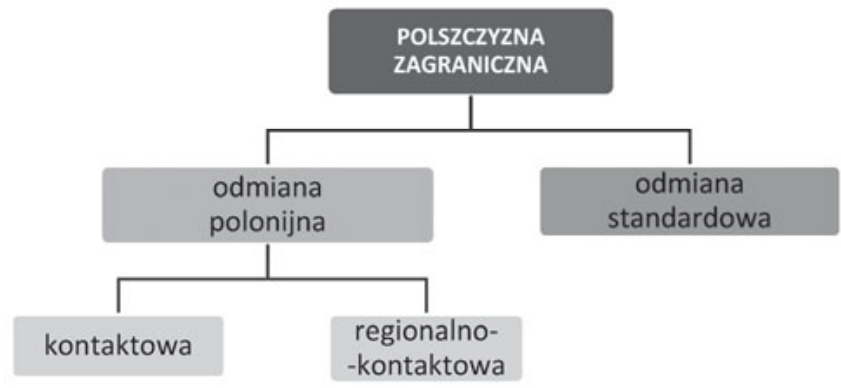

Diagram 1. Podział polszczyzny zagranicznej (opracowanie własne)

Standardową odmianą polszczyzny zagranicą posługują się ludzie wykształceni, posiadający wyższy stopień świadomości językowej i (na ogół) dbający o jej poprawność. Osoby te nierzadko pracują na rzecz Polonii: w szkołach, mediach, biurach tłumaczeń, teatrach, ośrodkach polonijnych lub w placówkach dyplomatycznych. Często jeżdżą do Polski, a w domu $z$ reguły rozmawiaja po polsku. Ich polszczyzna ${ }^{9}$ jest prawidłowa i czysta, ale sprawia nieraz wrażenie zbyt tradycyjnej, książkowej, trochę niemodnej. Powoduje to niekiedy zaburzenia w komunikacji z mieszkającymi w Polsce rodakami - zwłaszcza z młodszymi, którzy nie rozumieją rzadziej już używanego lub zapomnianego słownictwa. Wiele do życzenia pozostawia też ich wymowa i akcent, które zdradzają, że nie są „miejscowi”. Zagraniczni Polacy z kolei nie znają lingwistycznych nowinek, z trudem też akceptują wulgaryzację języka ojczystego.

\footnotetext{
${ }^{9}$ Mowa o interakcjach ustnych, w piśmie obie polszczyzny - krajowa i zagraniczna - są raczej zbieżne.
} 
Władysław Miodunka uważa, że używanie języka poza Polską zgodnie z normami obowiązującymi dla polszczyzny w Polsce jest typowe dla inteligencji twórczej, a jej przedstawiciele są w stanie zachować za granica polszczyznę literacką w nienaruszonym stanie (1990a, 12). Stanisław Dubisz i Elżbieta Sękowska $(1990,218)$ podkreślają z kolei, że „pojęcie normy językowej można odnieść tylko do części konkretyzacji odmiany pisanej i mówionej (teksty oficjalne i część artystycznych, niektóre przekazy prasowe, radiowe i telewizyjne), które w nieznacznym stopniu różnią się od standardowej polszczyzny".

Mimo że polszczyzna standardowa jest językiem wspólnym dla wszystkich Polaków, zagranicą ma niewielki zasięg komunikacyjny. Najważniejszą przyczyną jest fakt, że wśród emigrantów zawsze znacznie przeważali ci, którzy szukali lepszych warunków ekonomicznych, a większość z nich to ludzie słabo wykształceni, porozumiewający się różnymi odmianami polszczyzny głównie regionalnymi. Tym samym zagranicą znalazło się stosunkowo niewielu nosicieli polszczyzny kulturalnej, literackiej, normalizowanej i skodyfikowanej (zob. Miodunka 1990b, 40), dlatego zaznacza się brak poczucia normy polszczyzny standardowej wśród reprezentantów większości środowisk polonijnych oraz przekazywanego przez kolejne generacje zwyczaju językowego (zob. Dubisz, Sękowska 1990, 219).

Język polonijny ${ }^{10}$ to ustna odmiana polszczyzny o dość dużym zasięgu komunikacyjnym. Posługują się nim zazwyczaj osoby o niższym wykształceniu i statusie społecznym, mniej wrażliwe na poprawność wypowiedzi. Występuje w zagranicznych enklawach terytorialnych, dlatego określa się go mianem etnicznego kodu lokalnego. Stanisław Dubisz (1997a, 23) nazwał go „melanżem elementów języka polskiego (i jego wariantów), języka kraju osiedlenia i jezzyków innych grup etnicznych, z którymi polonijne zbiorowości wchodzą w bezpośredni kontakt”. Schematycznie przedstawia to diagram 2.

Z wymienionych elementów tylko język polski i jego warianty to stałe elementy języków różnych Polonii, choć - rzecz jasna - niejednakowe. Pozostałe to zmienne w znaczący sposób wpływające na postać danego języka polonijnego.

Intensywność i jakość styczności polszczyzny z innymi językami zależą m.in. od środowiska (chodzi np. o miejscowość czy dzielnicę, która determi-

10 W literaturze przedmiotu można spotkać określenie „dialekty polonijne” (zob. np. Dubisz 1997a, Sękowska 2010). Unikamy go ze względu na zbieżność z terminem z zakresu dialektologii, określającym mowę ludności wiejskiej. 
nuje kontakty rówieśnicze oraz sąsiedzkie ${ }^{11}$ ), od rodzaju oraz miejsca pracy czy od statusu socjalnego i ekonomicznego. Natomiast kluczową rolę w tym melanżu odgrywa język kraju osiedlenia (który, o czym nie wolno zapominać, jest nierozerwalnie związany kultura) interferujący w kod etniczny przybyszów. Wyjaśnijmy, że w klasycznym ujęciu interferencja oznacza wpływ języka pierwszego na docelowy w procesie jego opanowywania, jednak zanurzenie w nowym języku - zwłaszcza gdy staje się on kodem funkcjonalnie pierwszym - powoduje także kierunek odwrotny, czyli przenoszenie do języka natywnego elementów języka kraju osiedlenia. W tym właśnie kontekście zjawisko interferencji jest tu rozpatrywane.

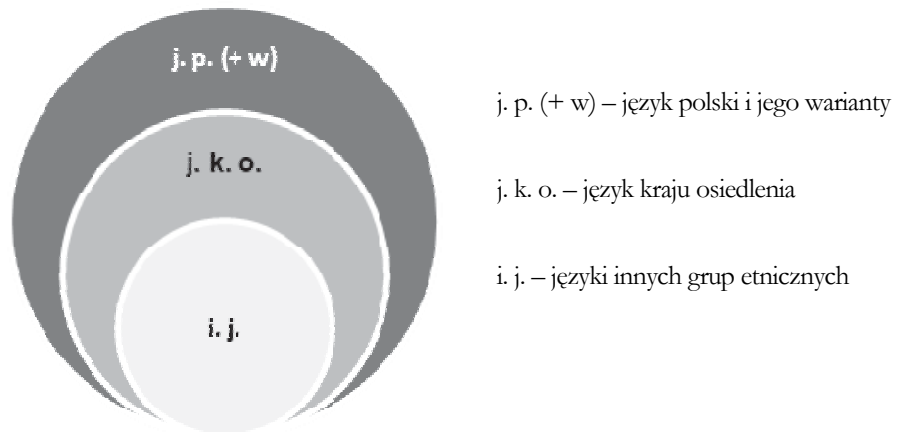

Diagram 2. Język polonijny - komponenty (opracowanie własne)

Interferencje obejmuja „,cytaty”, „zapożyczenia” oraz „kalki” (zob. szerzej m.in. Dubisz, Sękowska 1990, Sękowska 1994, Dubisz 1997c, Lipińska 2003; 2013). Na gruncie polonijnym trudno jest je rozróżnić, gdyż pojęcia te $z$ natury są nieostre, a w przypadku polszczyzny zagranicznej nabierają niuansów sui generis ${ }^{12}$. I tak - w odniesieniu do języka rodzimego - termin ,zapożyczenie” rozumiany jest jako: „element przejęty z obcego języka. Najczęściej jest nim wyraz, rzadziej prefiks lub sufiks” (EJO 1999, 668), „forma językowa przejęta z innego języka”, gdzie w zależności od stopnia upodobnienia rozróżnia się niezintegrowane lub tylko częściowo upodobnione wyrazy obce oraz wyrazy przyswojone (zob. Szulc 1994, 237) czy - jak podaje E. Sękowska $(2010,35)$ - „element obcy zintegrowany z systemem języka zapożyczającego (ojczystego)”. Badaczka uściśla, że „każda pożyczka ma na początku

11 Mowa o kontaktach Polaka z - przykładowo - językiem wietnamskim, niemieckim, serbskim (osobno lub razem) na gruncie australijskim.

12 To m.in. różnice regionalne, które mogą się wywodzić tak z J1, jak i z j.k.o. 
charakter cy ta tu [podkr. E.L.], a następnie dochodzi do adaptacji na czterech poziomach: graficznym, fonologicznym, morfologicznym i semantycznym, co prowadzi do dostosowania zapożyczenia do struktury języka zapożyczającego" (Sękowska 2010, 35; zob. też Walczak 2014). Bogdan Walczak zaś (2014) jest zdania, że w procesie przenikania obcych elementów do języka etnicznego na szczególną uwagę zasługują kalki, które sprawiają wrażenie form rodzimych, są więc z nimi mylone. Autor podkreśla, że „trzeba posiadać dobrą znajomość własnego języka, żeby dostrzec, że pod tą swojską szatą zewnętrzną kryją się obce wzory budowy, czyli obce prawa gramatyczne”. Przypomnijmy, że kalki definiuje się jako „formę językową, będącą mniej lub więcej dokładnym strukturalnym lub semantycznym odwzorowaniem odpowiedniej formy w innym języku” (Szulc 1994, 104) czy „wyraz lub wyrażenie utworzone za pomocą rodzimych elementów języka według wzoru semantycznego języka obcego. Rozróżnia się zwykle kalki leksykalne (wyrazowe i frazeologiczne), które są swego rodzaju dokładnymi tłumaczeniami obcych wzorów leksykalnych oraz kalki gramatyczne” (EJO 1999, 284).

Warto zatem częściej posługiwać się określeniem 'cytat(y)' oraz 'kalki', odnosząc się do charakterystyki języka polonijnego, a 'zapożyczenia' traktować z pewną ostrożnością, zwłaszcza, że „potwierdzeniem akceptacji zapożyczenia jest odnotowanie w słownikach, a o adaptacji wyrazu świadczą też derywaty od niego tworzone, a także wchodzenie w związki semantyczne: polisemiczne i homonimiczne" (Sękowska 2010, 35), co w przypadku języka polonijnego rzadko ma miejsce. Ponadto „normalne” zapożyczanie prowadzi do wzbogacenia języka ojczystego, jest świadome ${ }^{13}$, akceptowane i używane przez całą wspólnotę językową, stając się zjawiskiem społecznym (zob. Czochralski 1979, 524-525), czego w sytuacji emigracyjnej również brakuje.

Gwoli ścisłości dodajmy, że wyróżnia się interferencje indywidualne (zachodzące w mowie poszczególnych jednostek) oraz zbiorowe (powszechne w mowie grup lokalnych, środowisk, skupisk). Chociaż jedne i drugie powodują odchylenia od normy językowej, te pierwsze mogą pozostać tylko odchyleniami z tendencją do zanikania, drugie natomiast „mogą wejść na stałe w obręb zespołu środków językowych akceptowanych przez uzus i normę językową" (Dubisz 1997c, 330). Przyczyniają się wtedy do poszerzenia zasobu leksykalnego danego wariantu kodu polonijnego przy akceptacji jego

${ }^{13} \mathrm{~W}$ sensie sankcjonowania ich przez gremia odpowiedzialne za politykę językową. To „zapożyczenia całkowicie przyswojone”, a więc wyrazy mające zarówno polską fonetykę, jak i podlegające polskiemu systemowi fleksyjnemu. Najczęściej są zapożyczeniami historycznymi, należącymi już do systemu leksykalnego polszczyzny. 
użytkowników, co można uznać za efekt podobny do tego, który powoduja w J1 zapożyczenia całkowicie przyswojone.

Reasumując - język polonijny, zwłaszcza w postaci słuchowo-ustnej, jest kombinacją kodu prymarnego w różnych wariantach oraz języka kraju przyjmującego z mniejszą lub większą domieszką innych języków. Za najważniejsze jego cechy Anna Wierzbicka uważa:

wypełnianie luk w słownictwie rodzimym zapożyczeniami z języka osiedlenia, mieszanie konstrukcji składniowych obu języków przy jednoczesnym braku świadomości, że nie są to konstrukcje polskie, adaptowanie obcych elementów przez bezwiedne włączanie ich do polskich paradygmatów oraz do polskich typów słowotwórczych $(1997,227)$.

Autorka uwypukla fakt, że używanie języka polonijnego jest warunkowane określoną sytuacją pragmatyczną obejmującą wspólne doświadczenia rozmówców oraz ich wspólne uczestnictwo w innej niż polska rzeczywistości (Wierzbicka 1997, 227).

Interferencje są nierozerwalnie związane z przełączaniem kodów (szerzej zob. Lipińska 2003). Zjawisko to jest bardzo charakterystyczne dla użytkowników języka polonijnego. Polega na szybkim „przeskakiwaniu” z języka na język, co uwidocznia się w zmianie słowa, wypowiedzenia albo całego zdania. Jest to aktywny i kreatywny proces włączania materiału z obydwu języków, którymi włada dana osoba. Niektóre wyrazy lub ich grupy podlegaja regułom jednego języka, a inne - drugiego, co nie przeszkadza rozmówcom we wzajemnym rozumieniu się. Przełączanie kodów zachodzi prawie wyłącznie w czasie nieformalnych konwersacji, a bardzo rzadko w piśmie. Rozmówcy rozróżniają doskonale obydwa kody i wiedza, kiedy następuje przeskok z jednego na drugi. Przełączenie kodów może być:

- całościowe, które polega na zmianie języków w dużych partiach wypowiedzeniowych. Przypomina tłumaczenie obszernych fragmentów lub faktycznie nim jest. System taki stosują np. dzieci wychowywane w dwujęzycznych rodzinach: do ojca zwracają się w jednym języku, a do matki - w drugim (lub do rodziców i dziadków). To w rzeczywistości zmiana języków, która jest wyrazem wysokiej kompetencji bilingwalnej;

- fragmentarycżne (częściowe), oznaczające brak kompetencji dwujęzycznej. Jest to de facto mieszanie języków spowodowane wieloma czynnikami, wśród których najistotniejsze to: 
- niedostateczna znajomość J1 (już) lub J2 (jeszcze). Powstaje więc konieczność włączania obcych słów: nowych (tzn. bez znanego odpowiednika w języku ojczystym) lub wcześniej nieznanych (nazywających rzeczy lub zjawiska nowej rzeczywistości); chęć wyjaśnienia, rozwiania wątpliwości poprzez użycie właściwego (odpowiedniego) i znanego, zdaniem mówiącego, słowa lub zwrotu w języku bardziej znanym lub lepiej czy dokładniej wyrażającym daną myśl, rzecz czy zjawisko;

- przykładanie mniejszej wagi do poprawności i czystości języka;

- chęć wykluczenia kogoś z konwersacji;

- symboliczne podniesienie swojego statusu imigranta, własnego morale, pochwalenie się przed interlokutorem „znajomością” nowego języka.

Małgorzata Warchoł-Schlottmann (1994, 204), opisując środowisko polskie w Niemczech, tak odnosi się do tego zjawiska:

Czasem nie można oprzeć się wrażeniu, iż mieszanie języków ma charakter opacznie pojętego snobizmu, demonstracyjny - własnej dwujęzyczności albo manifestacji już takiego zintegrowania $\mathrm{z}$ nowym środowiskiem, takiego zespolenia językowego, że inaczej mówić niepodobna lub nie wypada.

Podobnie ujmuje to Anna Wierzbicka w kontekście polskości we Włoszech $(1997,226)$ : „Wplatanie włoskich elementów językowych do tekstów polskich ma świadczyć o większym obyciu z włoskimi realiami, jest znakiem wtajemniczenia, którego brak nowicjuszom dopiero co przybyłym z kraju”. Józef Porayski-Pomsta $(1997,215)$ podkreśla, że każdy język polonijny jest uboższy od j.k.o., stąd „psychologiczna potrzeba jego ciagłego uzupełniania”. Władysław Miodunka (1990b, 47) z kolei zwraca uwage na to, że dla pokolenia emigranckiego J1 nadal nazywa i porządkuje stary świat, ale też nazywa i porządkuje nowy świat (już zastany w kraju osiedlenia i nazywany w J2), a to powoduje, że ,J1 musi się zmienić, musi zmienić swą siatkę pojęciowa, głównie przez zapożyczenie nowych słów i wyrażeń oraz przez stworzenie słów nowych z elementów danych w J2".

Według A. Wierzbickiej $(1997,226)$ emigranci są świadomymi użytkownikami języka polonijnego, a posługują się nim ,tylko w rozmowach z innymi emigrantami, nie używając go natomiast w czasie wizyt składanych rodzinom mieszkającym w kraju ojczystym, chyba że rozmawiają między sobą”. 
Dorośli są więc w stanie powstrzymać się od mieszania kodów, ich dzieci natomiast, które opanowały język polonijny w takiej wersji, nie czują, że różni się on od wersji krajowej. Posługują się nim zatem we wszelkich kontaktach z Polakami, zarówno w kraju osiedlenia, jak i w Polsce ${ }^{14}$.

Mieszanie kodów sprzężone $z$ interferencją to cecha języka polonijnego w wersji słuchowo-ustnej. Uczestnicy takich interakcji rozumieją się nawzajem i ich komunikacja jest pełnowartościowa. Przebiega zdecydowanie szybciej, niż gdyby trzeba było oddzielać od siebie dwa języki przy próbach przekładu słów i wyrażeń (z konieczności w sposób opisowy). To jeszcze jeden, niewymieniony wcześniej powód przełączania kodów: ekonomia języka.

Przedstawiam hipotetyczną rozmowę dwóch osób ${ }^{15}$ - załóżmy, że koleżanek ze szkoły, z których jedna osiadła w anglojęzycznym (A), a druga - we francuskojęzycznym (F) kraju. Przypuszczalnie byłyby w stanie rozmawiać z Polakami w Polsce polszczyzną ogólna, jednak między sobą posługują się językiem polonijnym - każda swoim wariantem zdeterminowanym wymienionymi wcześniej czynnikami. Powodem może być nawyk, brak wyczucia popełnianych zniekształceń, nieprzykładanie wagi do poprawności, ale też pochwalenie się „znajomością” nowego języka przed rozmówczynią, która jest nie stąd, gdzie toczy się rozmowa, jest więc inną Polonuską. Czy się zrozumieją? Załóżmy też, że siedzi z nimi trzecia koleżanka ze szkoły, mieszkająca w Polsce - czy wie, o co chodzi w tej interakcji?

F

- Pardon za spóźnienie - nie mogłam się zagarować! Jutro chyba wezmę autobus.

- Pyszne to gato!
A

- Przedwczoraj mi stołowali auto, więc dziś Adam dał mi lifta. Ale natopuję kartę na tramwaj.

- Orginalnie chciałam wziąć kejk, ale ten ajskrim jest okej. Jak szoping?

14 Prowadzi to nieraz do przykrych sytuacji, kiedy zwracając się do rodaków w kraju, są przekonani, że mówią jak native speakerzy, a tymczasem nie zawsze są w stanie skutecznie się komunikować i często słyszą od sprzedawcy, kelnera czy fryzjerki: ,jak dobrze pan/i mówi polsku - skąd pan/i jest?” (zob. Lipińska, 2019).

15 Podane wypowiedzi nie są ułożone w formie dialogu z powodu ograniczonych ram tekstu. Przykłady pochodzą z: Masiewicz (1990), Porayski-Pomsta (1997), Dubisz (1997b), z zasłyszanych historii oraz obserwacji uczestniczących (Francja, USA, Australia). 
- Zrobiłam naprawdę dobrą aferę zobacz tyle rzeczy za prawie nic! Część jest az bin, ale ładne.

- Muszę jeszcze kupić kada dla koleżanek, a potem iść na pocztę, żeby odebrać list rekomendowany.

- Mój tato jest już na retrecie, ale czasem jeździ kamionetką i nadal lubi brykolować. Czyści też mokety.

- Moja mama ciagle chodzi do kine po tym akcydencie. Niedawno miała gastro.

- Nadal taki delikatny do jedzenia?

- A propos, kiedy tu można trafić na api auers? Codziennie po południu?

- Gdzie moje lunety? Chyba nie wrzuciłam ich do publa?

- Alan dalej lubi chodzić po brokantach?

- Zarejestrowałaś mi zdjęcia na kluczu?

- Napiszę słowo do trenera, że Filip nie będzie na pływaniu.

- Ciał!
- Kupiłam zegarek na speszjalu. Niestety, muszę go klajmować, bo nie pracuje.

- Muszę ewentualnie kupić jakieś gifty dla rodziców.

- Moja mama still chodzi na domki, a tato jeździ na trokerce. Aktualnie rentują trzybedrumowy flet przy lejku.

- Mojego męża ojciec jest na pensji, ale jest sik. Musi chodzić do chiroprakty.

- Jest bardzo fasi. Prawie codziennie je pampkin sup i czopsy.

- Ja nie myślę. Chyba tylko we frajdej.

- Byłabym wyrzuciła tikety do garbecia.

- Ach, musisz zobaczyć mój nowy bafej z sekendhendu - jest fantastik!

- Zasejwowałam ci zdjęcia na pendrajwie. To jutro Wieliczka?

- Sy ja!

To przykład przerysowany, jednak taka komunikacja jest, niestety, możli$w^{16}$. Pokazano ja w zakresie odmiany kontaktowej, lecz trzeba pamiętać

${ }^{16} \mathrm{~F}$ : (za)garować się [se garer] - (za)parkować; gato [gateau] - ciastko; kada [cadeaux] - prezenty; zrobić (dobra) aferę - tu: o udanych, oszczędnych, trafionych zakupach; az bin [ang. has been] - niemodny, przestarzały; rekomendowany - polecony; być na retrecie [retraite] - być na emeryturze; kamionetka - mała ciężarówka; brykolować [bricoler] - majsterkować; mokety [moquettes] - wykładziny, dywany; kine [kiné, od: kinésithérapie] - terapeuta, rehabilitant; akcydent [accident - wypadek; gastro - grypa żołądkowa; api auers [ang. happy hours]; lunety [lu- 
o odmianach regionalno-kontaktowych, które jeszcze bardziej różnicują ${ }^{17}$ języki polonijne.

Podsumowując, pragnę wyrazić przekonanie, że:

Wewnętrzne zróżnicowanie zbiorowości polonijnych wyklucza występowanie jednego monolitycznego dialektu czy socjolektu polonijnego. W gruncie rzeczy każde środowisko polonijne posługuje się kodem różniącym się od sposobów porozumiewania się innych środowisk. Różnice te są niejednokrotnie niewielkie i trudne do ustalenia bez szczegółowych badań empirycznych (Dubisz, Sękowska 1990, 220).

\section{Literatura}

Czochralski J., 1979, O interferencji jezyykowej, w: Grucza F., red., Polska myśl glottodydaktyczna 1945-1975. Wybór artykutów z. zakeresu glottodydaktykei ogólnej, Warszawa.

Dubisz S., 1997a, Jezyk polski poza granicami kraju - wstępne informacje i definicje, w: tegoż, red., Jezyk polski poza granicami kraju, Opole.

Dubisz S., 1997b, Polonia i jej jezylk w Stanach Zjednoczonych Ameryki Pótnocnej w: tegoż, red., Jezyk polski poza granicami kraju, Opole.

Dubisz S., 1997c, Jezyk polski poza granicami kraju - próba charakterystykei kontrastowej, w: tegoż, red., Jezyke polski poza granicami kraju, Opole.

Dubisz S., Sękowska E., 1990, Typy jednostek leksykalnych w socjolektach polonijnych (próba definicji i klasyfikacji), w: Miodunka W., red., Jezyk polski w świecie. Zbiór studiów, Warszawa.

Encyklopedia jezykoznawstwa ogólnego, (EJO), Polański K., red., 1999, wyd. II popr. i uzup., Wrocław.

nettes] - okulary; pubel [poubelle] - kosz na śmieci; brokanty [brocante] - pchli targ, targ staroci; zrejestrować - zapisać; klucz - pendrive; słowo [parole] - usprawiedliwienie, wyjaśnienie; ciał [wł. ciao]; A: (s)tołować [to tow] - holować; dać lift(a) [to give a lift] - podrzucić; natopować [to top up] - naładować; orginalnie - pierwotnie, początkowo, kejk [cake] - ciastko, ajskrim [ice-cream] - lody; szoping [shopping] - zakupy; na speszjalu [special] - okazyjnie, na wyprzedaży; klajmować [to claim] - tu: reklamować; nie pracuje - nie funkcjonuje; ewentualnie - ostatecznie, wreszcie; gifty [gifts] - prezenty; still - ciagle; chodzi na domki - sprząta; trokerka (trok) [truck] - ciężarówka; rentować [to rent] wynajmować; trzybedrumowy [bedroom] - „trzysypialniowy"; flet [flat] - mieszkanie; lejk [lake] - jezioro; pensja [pension] - emerytura; sik [sick] chory; chiroprakta [chiropractor] - kręgarz, rehabilitant; aktualnie - w rzeczywistości, prawdę mówiąc; fasi [fussy] - wybredny, kapryśny; pampkin sup [pumpkin soup] - zupa dyniowa; czopsy [chops] - kotlety; ja nie myślę - nie sądzę; we frajdej [Friday] - w piątek; tikety [tickets] - bilety; garbeć [garbage] - śmieci; bafej [fr. buffet] - tu: kredens; sekenhend [second hand] - z drugiej ręki, używany; rili [really] - naprawdę; fantastik [fantastic] - fantastyczny; zasejwować [to save] zachować, zapisać; pendrajw - pendrive; sy ja [see you] - do zobaczenia

${ }_{17} \mathrm{Na}$ przykład w Paryżu osiedla się sporo ludzi z Podlasia, do Lille przybywali górnicy ze Śląska. Każda grupa posługuje się innym językiem regionalnym. 
Kubiak H., 1990, Zanikajace pokrewieństwo. Szkice socjologiczne o Polonii, Kraków.

Lipińska E., (2019), Szok kulturowy, jezykowy i tożsamościony pokolenia emigracyjnego - triadyczny układ zależności, „Kwartalnik Polonicum”, nr 31/32.

Lipińska E., 2018, Jezylk ojczysty - kod wspólny cay wtasny?, w: Polonistyka w XXI wieku: między lokalnym a globalnym. Praca zbiorowa z. okazji 190-lecia filologii polskiej na Uniwersytecie Lwowskim, Kijów.

Lipińska E., 2017, Polska polityka jezykowa wobec zagranicznego jezykea ojczystego, w: Kubicka E., Berend M., Rittner M., red., Nowe perspektywy w nauczaniu jezykea polskiego jako obcego IV, Toruń.

Lipińska E., 2016, Zachowanie własnych i prayswojenie obych wartości - o kulturowych $i$

jezykowych konsekwencjach emigracji z. Polski do Australii, „Postscriptum Polonistyczne”, nr 1 (17).

Lipińska E., 2013, Polskosśc w Australii - o dwujezyczności, edukacji i problemach adaptacyjnych Polonii na antypodach, Kraków.

Lipińska E., 2007, Międyy 'emigracja' a 'Poloniq' - pierwsze pokolenie polonijne, w: Prace

Filologiczne, t. LIII, Warszawa.

Lipińska E., 2006, Polskość mtodzৃieży polonijnej, w: Nadolski M., Rybczyński W., red., Polonia i Polacy w Unii Europejskiej. Praca zbiorowa, Pułtusk.

Lipińska E., 2003, Jezylk ojczysty, jezyle oby, jezyle drugi. W stęp do badań dwujezycz̨ności, Kraków.

Lipińska E., Seretny A., 2018, Od jezykea pierwszego przez odziedziczony i drugi do jezy/ka ojczystego o polsžczyźnie polskiego uczৃnia imigranta/ reemigranta, w: Gębal P.E., red., Edukacja wobec migracji. Konteksty glottodydaktyczne i pedagogiczne. Monografia zbiorowa, Kraków.

Masiewicz A., 1990, Jezyk Polonii francuskiej, w: Miodunka W., red., Jezyk polski w świecie. Zbiór studión, Warszawa.

Miodunka W., 1990a, Wstęp, w: tegoż, red., Jezyke polski w świecie. Zbiór studiów, Warszawa.

Miodunka W.,1990b., Moc jezyka i jej znaczenie w kontaktach jezykowych i kulturowych, w: tegoż, red., Jezyke polski w świecie. Zbiór studiów, Warszawa.

Paluch A., 1976, Inklusymne i eksklusymne rozumienie terminu „Polonia”, „Przegląd Polonijny”, z. 2.

Porayski-Pomsta J., 1997, Jezyk polski we Francji, w: Dubisz S., red., Jezyk polski poza granicami kraju, Opole.

Porayski-Pomsta J., 1989, Problemy nauczania jezykea polskiego w środowiskach polonijnych, w: Rybicka-Nowacka H., Porayski-Pomsta J., red., Wybór materiatów z konferencji: Problemy nauczania jezykea polskiego w środowiskach polonijnych, „Polonistyka”, nr 4.

Sękowska E., 2010, Jesyke emigracji polskiej w świecie. Bilans i perspektyny badawçe, Kraków.

Sękowska E., 1994, Jezyke zbiorowości polonijnych w krajach anglojezycznych. Zagadnienia leksykealno-stowotwórcze, Warszawa.

Szulc A., 1994, Stownik dydaktyki jezyków obych, Warszawa.

Walaszek A., red., 2001, Polska diaspora, Kraków [z okładki].

Walczak B., 2014, Trzy refleksje o dwujezyczności, https://pressto.amu.edu.pl/index.php/psj/ article/view/619/541 [dostęp: 2.03.2019].

Warchol-Schlottmann M., 1994, Próba opisu kompetencji jezylkowej w niemieckim i polskim u Polaków $w$ Niemczech - studium socjolingwistyczne. Niepublikowana rozprawa doktorska, Kraków.

Wierzbicka A., 1997, Włoski jezyk polonijny, w: Dubisz S., red., Jezyk polski poza granicami kraju, Opole. 


\section{Netografia}

https://www.msz.gov.pl/pl/polityka_zagraniczna/polonia/definicje_pojecia/, 2012 r. [dostęp: 11.02.2019]. 